\title{
PENGGUNAAN BASIS AKRUAL DALAM LAPORAN KEUANGAN PEMERINTAH KABUPATEN WATAMPONE
}

\author{
Rustan $^{1}$ Muhammad Chaikal' \\ Universitas Muhammadiyah Makassar \\ e-mail : d3pajak@unismuh.ac.id
}

\begin{abstract}
Research aims to determine the use of the accrual base in the financial statements of Watampone District government. The approach used in this research is a qualitative approach. The approach used in this research is a qualitative approach. The research object is located in the research location of the Office of Financial management and regional assets. While the time of this research will be implemented for 2 (two) months. The types of data used in this research are qualitative data, while the source of data obtained in this research is a secondary source. The results of this study show that the financial management apparatus in Bone District government has been aware of the accounting of the accrual base government like what. Government strategy in applying accounting base accrual has been running well in the district of BPKAD Bone and one of the constraints of the preparation of the accrual-based financial statements that are still turtles
\end{abstract}

Keywords: accounting, accrual bases and financial statements

\begin{abstract}
Abstrak
Penelitian ini bertujuan untuk mengetahui penggunaan basis akrual dalam laporan keuangan pemerintah kabupaten watampone. Pendekatan yang digunakan dalam penelitian ini adalah pendekatan kualitatif. Pendekatan yang digunakan dalam penelitian ini adalah pendekatan kualitatif. Objek Penelitian ini berlokasi lokasi penelitian pada kantor Dinas Pengelolaan Keuangan dan Aset Daerah. Sedangkan waktu penelitian ini akan dilaksanakan selama 2 (dua) bulan. Adapun jenis data yang digunakan dalam penelitian ini adalah data kualitatif, sedangkan Sumber data yang diperoleh dalam penelitian ini adalah sumber sekunder. Hasil penelitian ini menunjukkan menunjukkan bahwa aparat pengelola keuangan di pemerintah Kabupaten Bone telah mengetahui akuntansi pemerintahan basis akrual itu seperti apa. Strategi pemerintah dalam menerapkan akuntansi Basis Akrual sudah berjalan dengan baik dilingkungan BPKAD Kabupaten Bone dan salah satu kendala penyusunan laporan keuangan berbasis akrual yaitu masih kurangnya sumber daya manusia yang mengetahui atau menguasai secara penuh atau secara keseluruhan bagaimana teknik penyusunan laporan keuangan berbasis akrual karena penyusunan laporan keuangan berbasis akrual lebih sulit dibandingkan berbasis kas hal itu disebabkan oleh adanya pos-pos piutang, hutang dan penyusutan yang muncul. Sehingga menyebabkan keterlambatan pelaporan keuangan TA 2015.
\end{abstract}

Kata Kunci: Akuntansi, Basis Akrual dan Laporan Keuangan 


\section{PENDAhuluan}

Perkembangan Akuntansi Sektor publik yang semakin pesat, hal ini disebabkan karena adanya era reformasi dalam pelaksanaan kebijakan pemerintahan otonomi daerah dan desentralisasi fiskal yang menitik beratkan pada pemerintah daerah. Dalam salah satu penjelasan di Undang-undang Perbendaharaan Negara disebutkan bahwa SAP ditetapkan dalam suatu peraturan pemerintah yang saat ini diatur dengan PP No. 71 Tahun 2010. SAP merupakan persyaratan yang mempunyai kekuatan hukum dalam upaya peningkatan kualitas laporan keuangan pemerintah di Indonesia. Pemerintah selanjutnya mengamanatkan tugas penyusunan standar tersebut kepada suatu komite standar independen yang ditetapkan dengan suatu keputusan presiden tentang Komite Standar Akuntansi Pemerintahan (KSAP).

Ketentuan dalam Undang-Undang Nomor 17 Tahun 2003 Pasal 36 Ayat (1) tentang Keuangan Negara yang mengamanatkan penggunaan basis akrual dalam pengakuan dan pengukuran pendapatan dan belanja untuk dilaksanakan selambat-lambatnya Dalam 5 (lima) tahun. Berlakunya Peraturan Pemerintah Nomor 71 Tahun 2010 tentang SAP berbasis akrual membawa perubahan besar dalam sistem pelaporan keuangan di Indonesia, yaitu perubahan dari basis kas menuju akrual. Hingga terbit Peraturan Pemerintah No. 71 Tahun 2010 tentang Standar Akuntansi Pemerintahan untuk mengganti PP No. 24 Tahun 2005. Pada PP No. 71 Tahun 2010 batas waktu penerapan sistem akuntansi akrual secara penuh (full accrual) diundur sampai dengan tahun 2014. SDM yang kompeten dan andal di bidang akuntansi. Oleh karena itu pemerintah pusat dan daerah perlu secara serius menyusun perencanaan dan penempatan sumber daya manusia di bidang akuntansi pemerintahan.

Faktor lain yang tidak kalah penting adalah komitmen dari organisasi/instansi dalam hal ini yang berwenang dalam pengambilan keputusan adalah pimpinan organisasi itu sendiri. Dukungan yang kuat dari pimpinan merupakan kunci keberhasilan dari suatu perubahan. Salah satu penyebab kelemahan penyusunan Laporan Keuangan pada beberapa Kementerian/Lembaga adalah lemahnya komitmen pimpinan satuan kerjak hususnya BPKD (Badan Pemeriksa Keuangan Daerah) penerima dana Dekonsentrasi/Tugas
Pembantuan. Terkait dengan hal tersebut, pemerintah Kota Bone harus melakukan berbagai persiapan, seperti penyusunan sistem akuntansi pemerintahan berbasis akrual.

\section{TINJAUAN PUSTAKA}

\section{Akuntansi}

Pengertian akuntansi dapat dijelaskan melalui dua pendekatan yaitudari segi proses dan dari segi fungsinya. Dilihat dari segi prosesnya,akuntansi adalah suatu keterampilan dalam mencatat, menggolongkan danmeringkas transaksitransaksi keuangan yang dilakukan oleh suatu lembagaatau perusahaan serta melaporkan hasil-hasilnya di dalam suatu laporan yang disebut sebagai laporan keuangan.

\section{Basis Akutansi}

Basis akuntansi merupakan prinsip-prinsip akuntansi yang menentukan kapan pengaruh atas transaksi atau kejadian harus diakui untuk tujuan pelaporan keuangan. Untuk menentukan kapan suatu transaksi itu harus diakui, tentunya harus menganalisis pengaruh transaksi terhadap perkiraan perkiraan pada laporan keuangan. Basis Akuntansi terdiri dari:

\section{a. Basis Kas}

Basis kas merupakan pencatatan yang hanya dilakukan pada saat diterima kas ataupun di keluarkan kas. Dengan kata lain tidak ada pencatatan kalau tidak ada transaksi penerimaan kas atau pengeluaran kas. Sebagai contoh adalah Buku Kas Umum dan buku pembantu yang dikelola oleh Bendahara Penerimaan dan Bendahara Pengeluaran karena pencatatan hanya dilakukan untuk penerimaan dan pengeluaran kas ataupun tidak ada pencatatan kalau tidak ada penambahan dan pengurangan kas di Bendahara Pemerintah.

\section{b. Basis akrual}

Basis akrual merupakan pencatatan yang dilakukan pada saat timbul hak dan kewajiban. Timbulnya hak tentunya akan mengakibatkan penerimaan, tapi penerimaan atas hak yang dimaksud dapat terjadi pada periode sekarang ataupun periode yang akan datang. Tapi yang pasti sudah merupakan hak walaupun belum diterima. Pencatatan tetap harus dilakukan supaya hak tersebut tercantum pada laporan keuangan. 


\section{Tujuan dan manfaat penerapan basis akrual.}

Secara sederhana, dikatakan bahwa penerapan akuntansi berbasis akrual ditujukan untuk mengatasi ketidak cukupan basis kas untuk memberikan data yang lebih akurat. Dalam presentasinya, Heather Thompson, Project Manager dari Transition from Cash to Accrual Accounting Project, Public Expenditure Management, pemerintah BARBADOS, menyampaikan beberapa tujuan penggunaan basis akrual yakni sebagai berikut:

a. Untuk meningkatkan efisiensi dan efektivitas sistem keuangan (penganggaran, akuntansi dan pelaporan) dalam sektor publik.

b. Untuk meningkatkan pengendalian fiskal, manajemen aset dan budaya sektor pulic.

c. Untuk meningkatkan akuntabilitas dalam program penyediaan barang dan jasa oleh pemerintah.

d. Menyediakan informasi yang lebih lengkap bagi pemerintah untuk pengambilan keputusan.

e. Untuk mereformasi sistem anggaran belanja (apropriasi).

f. Untuk mencapai transparansi yang lebih luas atas biaya pelayanan yang dilakukan oleh pemerintah

\section{METODE}

\section{Pendekatan Penelitian}

Pendekatan yang digunakan dalam penelitian ini adalah pendekatan kualitatif. Objek Penelitian ini berlokasi lokasi penelitian pada kantor Dinas Pengelolaan Keuangan dan Aset Daerah. Sedangkan waktu penelitian ini akan dilaksanakan selama 2 (dua) bulan. Adapun jenis data yang digunakan dalam penelitian ini adalah data kualitatif, sedangkan Sumber data yang diperoleh dalam penelitian ini adalah sumber sekunder.

a. Tahapan-Tahapan Analisis Data

Tahapan-tahapan analisis data dalam penelitian ini sebagai berikut:

1) Pengumpulan kategori, peneliti mencari suatu kumpulan data dan mengategorikannya sesuai dengan karakteristik data tersebut. Dalam konteks penelitian ini, peneliti akan mencari data-data mengenai proses laporan keuangan daerah yang disesuaikan dengan standar akuntansi pemerintahan berbasis akrual dan data-data yang diperoleh dari wawancara langsung terhadap aktor-aktor yang menjalankanstandar.
2) Interpretasi langsung, peneliti akan menarik langsung makna dari sebuah data yang telah diperoleh. Jadi, setelah memperoleh data laporan keuangan daerah Pemerintah kabupaten Bone serta data-data sosial yang berkaitan dengan teori institusional, maka peneliti akan menginterpretasikan secara langsung bagaimanakah implementasi standar akuntansi pemerintahan berbasis akrual.

3) Pengambilan keputusan, peneliti akan menarik kesimpulan secara umum (general) mengenai kondisi nyata (natural) yang terjadi di Pemerintah Kabupaten Bone tentang bagaimana implementasi standar akuntansi pemerintahan berbasis akrual

Setelah data dari lapangan terkumpul dengan menggunakan metode pengumpulan data di atas, maka peneliti akan menganalisis data tersebut dengan menggunakan pendekatan interpretif. Pendekatan interpretif merupakan suatu teknik menginterpretasikan arti data-data yang telah terkumpul dengan memberikan perhatian dan merekam sebanyak mungkin aspek situasi yang diteliti pada saat itu, sehingga memperoleh gambaran secara umum dan menyeluruh tentang keadaan sebenarnya.

\section{Teknik Analisis Data}

Adapun Teknik analisis data yang digunakan untuk menguji adalah Analisa data dilakukan dengan menggunakan deskriptif kualitatif yaitu Teknik yang dipakai dalam menganalisis data adalah metode deskriptif. Metode deskriptif menurut Indriantoro dan Supomo (2002:26), merupakan penelitian terhadap masalahmasalah yang berupa fakta saat ini dari suatu populasi. Penelitian ini menggunakan deskripsi analisis. Metode analisis untuk mengumpulkan, menganalisis dan menginterpretasikan data untuk memberikan penjelasan lengkap mengenai penelitian. Ciri-ciri pokok dari jenis penelitian deskriptif ialah:

a. Memusatkan perhatian pada masalahmasalah yang ada pada saat penelitian dilakukan (saat sekarang) atau masalahmasalah yang bersifat aktual.

b. Menggambarkan fakta-fakta tentang masalah yang diselidiki sebagaimana adanya, diiringi dengan interpretasi rasional yang cukup

c. Tidak terdapat manipulasi atau control variable yang dilakukan oleh peneliti.

Penelitian dalam tugas akhir ini merupakan jenis penelitian deskriptif yang lebih bersifat 
analisis penerapan Standar Akuntansi Pemerintahan yang Berbasis Akrual pada Laporan Keuangan Daerah Kabupaten Bone. Tujuan dari dilakukannya penelitian deskriptif ini ialah untuk mengetahui implementasi dari konsep akrual basis dalam pelaporan keuangan Daerah Kabupaten Bone selama kurun waktu tertentu.

\section{HASIL DAN PEMBAHASAN}

\section{Hasil}

Standar Akuntansi Pemerintahan (SAP) merupakan salah satu ujung tombak dari sebuah pengelolaan keuangan daerah yang baik, akuntabel, dan transparan. Memiliki standar akuntansi pemerintahan yang baku telah menjadi harapan bangsa Indonesia sejak masa reformasi. Hal ini sesuai dengan pernyataan Bastari (2004) bahwa implementasi UU No. 25 Tahun 1999 Tentang Perimbangan Keuangan antara Pusat dan Daerah dan PP No. 105 Tahun 2000 Tentang Pokok-Pokok Pengelola dan Pertanggungjawaban Keuangan Daerah tidak dapat terlaksana dengan baik karena pada saat itu belum memiliki pedoman yang jelas secara teknis mengenai pembuatan laporan keuangan. Setelah itu, pemerintah melakukan kajian dan langsung mengeluarkan paket undang-undang di bidang reformasi keuangan khususnya akuntansi pemerintahan yakni dimulai dari UU No. 17 Tahun 2003 Tentang Keuangan Negara, PP No. 24 Tahun 2005 Tentang Standar Akuntansi Pemerintahan (Cash Towards Accrual), PP No. 71 Tahun 2010 Tentang Standar Akuntansi Pemerintahan (Accrual), dan puncaknya berada pada Permendagri No. 64 Tahun 2013 Tentang Penerapan Standar Akuntansi Pemerintahan Berbasis Akrual pada Pemerintah.

Dengan turunnya Permendagri No. 64 Tahun 2013 Pasal 10 Ayat (2) yang menyebutkan bahwa "Penerapan SAP berbasis akrual pada pemerintah daerah paling lambat mulai tahun anggaran 2015" inilah yang membuat seluruh pemerintah daerah, termasuk Pemerintah Kabupaten Bone mau tidak mau harus mempersiapkan diri untuk menerapkan Standar Akuntansi Pemerintahan (SAP) Berbasis Akrual. Data yang dikumpulkan peneliti melalui wawancara dengan seorang informan, menunjukkan bahwa aparatur pengelola keuangan pemerintah Kabupaten Bone ketika ditanyakan mengenai standar akuntansi pemerintahan berbasis akrual, mereka sudah tahu akan definisi dari basis akrual itu sendiri, seperti yang di katakan oleh Kabid Akuntansi Badan Pengelolaan Keuangan dan Aset Daerah Kabupaten Bone bahwa akuntansi basis akrual itu merupakan suatu basis dimana transaksi ekonomi.

Dari pandangan informan di atas terhadap pengertian basis akrual, dapat dikatakan bahwa aparat pengelola keuangan di pemerintah Kabupaten Bone telah mengetahui akuntansi pemerintahan basis akrual itu seperti apa. Hal ini diperkuat juga dengan pemaparan yang diuraikan oleh Ibu Husnani selaku Kabid Akuntansi BPKAD Kabupaten Bone. Beliau mengatakan bahwa akuntansi berbasis akrual itu kita langsung mengakui pendapatan pada saat transaksi terjadi. Dan memberikan gambaran yang lebih akurat atas kondisi keuangan instansi/pemerintah daripada akuntansi basis kas.

Saat ditanyakan lebih lanjut mengenai strategi pemerintah dalam menerapkan akuntansi Basis Akrual sudah berjalan dengan baik dilingkungan

BPKAD Kabupaten Bone, beliau menjawab "pemerintah daerah telah bersinergi dengan pemerintah pusat terkait penerapan basis akrual dengan melakukan berbagai persiapan awal antara lain:

a. penyediaan sarana dan prasarana ;

b. peningkatan kapasitas SDM;

c. Penyesuaian regulasi tentang basis akrual.

Awal mula proses institusionalisasi dalam implementasi SAP basis akrual di Pemerintah Kabupaten Bone terjadi ketika Kementerian Dalam Negeri mulai mengeluarkan aturan untuk menerapkan SAP basis akrual paling lambat tahun 2015. Dari pernyataan tersebut telah terlihat tentang bagaimana awal mula implementasi SAP basis akrual ini dapat benarbenar terlaksana di tingkat pemerintah daerah. Setelah berbagai macam perkenalan mengenai SAP berbasis akrual yang dijelaskan melalui sosialisasi, bimtek, dan banyak pelatihan lainnya, Pemerintah Kabupaten Bone mulai melakukan strateginya tentang bagaimana SAP basis akrual ini dapat terlaksana pada tahun 2015.

\section{Pembahasan}

a. Makna Basis Akrual Pemerintah Kabupaten Bone: Kompleksitas Laporan Keuangan

Rata-rata aparatur pengelola keuangan pemerintah Kabupaten Bone ketika ditanyakan 
tentang standar akuntansi pemerintahan berbasis akrual, mereka sudah matang akan definisi dari basis akrual itu sendiri. Ibu Husnani mengatakan bahwa: Basis akrual adalah metode akuntansi dimana penerimaan dan pengeluaran diakui atau dicatat ketika transaksi terjadi, bukan ketika uang kas untuk transaksi-transaksi tersebut diterima atau dibayarkan dan memberikan gambaran yang lebih akurat atas kondisi keuangan instansi/ pemerintah daripada akuntansi berbasis kas. Pandangan informan di atas telah sesuai dengan makna basis akrual seperti yang telah disimpulkan oleh KSAP, yaitu suatu basis akuntansi di mana transaksi ekonomi dan peristiwa lainnya diakui, dicatat, dan disajikan dalam laporan keuangan pada saat terjadinya transaksi tersebut, tanpa memerhatikan waktu kas atau setara kas diterima atau dibayarkan.

Dari pandangan informan di atas terhadap pengertian basis akrual, dapat dikatakan bahwa rata-rata pengelola laporan keuangan pemerintah Kabupaten Bone telah menyadari adanya pergantian standar akuntansi pemerintahan yang saat ini berlaku yaitu peraturan pemerintah nomor 71 tahun 2010 tentang standar akuntansi pemerintahan berbasis akrual. Walaupun secara nyata, jenis laporan keuangan yang secara kuantitas seperti terlihat banyak tersebut, kalau diteliti lebih lanjut sebenarnya hanya pengembangan dari yang sudah ada dan nantinya justru akan menunjukkan artikulasi yang semakin jelas antar laporan keuangan.

Walaupun secara nyata, jenis laporan keuangan yang secara kuantitas seperti terlihat banyak tersebut, kalau diteliti lebih lanjut sebenarnya hanya pengembangan dari yang sudah ada dan nantinya justru akan menunjukkan artikulasi yang semakin jelas antar laporan keuangan. Namun, bagi para pengelola keuangan pemerintah Kabupaten Bone, kompleksitas pelaporan keuangan yang dihasilkan oleh PP 71/2010 semakin nampak dengan tidak adanya keterkaitan antara pelaporan pelaksanaan anggaran (akuntansi anggaran) dengan pelaporan finansial (akuntansi keuangan). Pemisahan antara akuntansi keuangan dengan akuntansi anggaran ini disebut dengan extra countable atau pencatatan terpisah antara akuntansi dengan anggaran. Dengan demikian, hal ini pastinya memerlukan analisa yang berbeda.
Secara teoritis, penelitian ini memberikan sebuah implikasi bahwa kondisi yang dialami oleh Pemerintah Kabupaten Bone saat ini dalam mengimplementasikan standar akuntansi pemerintahan berbasis akrual merupakan hal baru yang mana hampir setiap SKPD menjalankan ini karena bentuk ketaatan dan tanggung jawab mereka sebagai organisasi pemerintahan. Secara teoritis, penelitian ini memberikan sebuah implikasi bahwa kondisi yang dialami oleh Pemerintah Kabupaten Bone saat ini dalam mengimplementasikan standar akuntansi pemerintahan berbasis akrual merupakan hal baru yang mana hampir setiap SKPD menjalankan ini karena bentuk ketaatan dan tanggung jawab mereka sebagai organisasi pemerintahan.

b. Analisis Kendala dalam Implementasi Basis Akrual Pada Laporan Keuangan BPKAD Kabupaten Bone

Dalam penyajian laporan keuangan BPKAD Kabupaten Bone yang mengikuti Standar Akuntansi Pemerintahan berbasis akrual terdapat kendalakendala. Salah satu kendala yang dihadapi yaitu masih kurangnya sumber daya manusia yang mengetahui atau menguasai secara penuh atau secara keseluruhan bagaimana teknik penyusunan laporan keuangan berbasis akrual karena penyusunan laporan keuangan berbasis akrual lebih sulit dibandingkan berbasis kas hal itu disebabkan oleh adanya pos-pos piutang, hutang dan penyusutan yang muncul.

Kurangnya sumber daya manusia dapat dibuktikan dengan keterlambatannya pelaporan keuangan Tahun Anggaran 2015, pemerintah Kabupaten Bone dalam menyampaikan laporan keuangan (BPK-RI) pada tanggal 22 April 2016 berdasarkan nomor surat 900/654/IV/DPKAD/2016 tanggal 16 April 2016 perihal jadwal penyerahan LKPD TA. 2015. Atau mengalami keterlambatan dari ketentuan PP 58 Tahun 2005 tentang

Pengelolan Keuangan Daerah. Hal ini diakibatkan penerapan basis akrual

\section{KESIMPULAN DAN SARAN}

\section{Kesimpulan}

Berdasarkan penelitian yang dilakukan oleh peneliti pada penerapan basis akrual dalam pelaporan keuangan daerah oleh BPKAD Kabupaten Bone menunjukkan bahwa aparat 
pengelola keuangan di pemerintah Kabupaten Bone telah mengetahui akuntansi pemerintahan basis akrual itu seperti apa. Strategi pemerintah dalam menerapkan akuntansi Basis Akrual sudah berjalan dengan baik dilingkungan BPKAD Kabupaten Bone dan salah satu kendala penyusunan laporan keuangan berbasis akrual yaitu masih kurangnya sumber daya manusia yang mengetahui atau menguasai secara penuh atau secara keseluruhan bagaimana teknik penyusunan laporan keuangan berbasis akrual karena penyusunan laporan keuangan berbasis akrual lebih sulit dibandingkan berbasis kas hal itu disebabkan oleh adanya pos-pos piutang, hutang dan penyusutan yang muncul. Sehingga menyebabkan keterlambatan pelaporan keuangan TA 2015.

Meskipun secara nyata, jenis laporan keuangan yang secara kuantitas seperti terlihat banyak tersebut, kalau diteliti lebih lanjut sebenarnya hanya pengembangan dari yang sudah ada dan nantinya justru akan menunjukkan artikulasi yang semakin jelas antar laporan keuangan. Namun, bagi para pengelola keuangan pemerintah Kabupaten Bone

\section{Saran}

Dengan kondisi yang demikian, peneliti ingin memberikan saran bagaimana penerapan standar akuntansi pemerintahan berbasis akrual ini bisa dilaksanakan dengan baik, yakni sebagai berikut

a. Melakukan edukasi kepada para SKPD mengenai pemaknaan secara mendalam tentangakuntansi berbasis akrual. Karena hal ini penting agar para SKPD memiliki mindset yang cukup kuat tentang basis akrual dan apa kelebihannya. Sehingga, SKPD tidak bersifat gugur kewajiban setelah mampu melaksanakan basis akrual ini.

b. Pemerintah harus memperhatikan lagi mengenai kondisi SDM, karena sebenarnya perlu untuk mendapatkan SDM yang lebih kompeten dengan memiliki latar belakang pendidikan akuntansi

c. Perlu melakukan koordinasi antara SKPDSKPD (BKD, Inspektorat) terkait dalam proses penerapan standar akuntansi pemerintahan berbasis akrual ini, agar memiliki masukanmasukan dari berbagai pihak. Sehingga dapat dilakukan kajiankajian secara mendalam tentang standar akuntansi pemerintahan berbasis akrual.

\section{REFERENSI}

Agus, Puji, dan Riyanto. 2015. Akuntansi Pemerintah Daerah Berbasis Akrual. Bandung: Pustaka Pelajar

Arikunto. 2005. Metode Penelitian Kualitatif. Jakarta: Sagung Seto.

Bahar, Ewid, dan Rafika. 2015. Implementasi Akuntansi Berbasis Akrual. Universitas Diponegoro, Semarang. dan $R \& D$. Bandung: Alfabeta

Dora, sopia. 2014. Analisis Kesiapan Pemerintah Dalam Menerapkan Standar Akuntansi Pemerintah Berbasis Akrual. Universitas HKBP, Medan.

Faradillah, Andi. 2013. Analisis Kesiapan Pemerintah Daerah Dalam Menerapkan Standar Akuntansi Pemerintah. Universitas Hasanuddin Makassar, Makassar.

Kusuma. 2013. Analisis Kesiapan Pemerintah Dalam Menerapkan Standar Akuntansi Pemerintah Berbasis Akrual. Kabupaten Jember.

Pemerintah Republik Indonesia. 2003. UndangUndang Nomor 17 Tahun 2003 tentang Keuangan Negara Pasal 36 Ayat (1). Jakarta

Pemerintah Republik Indonesia. 2004. Undang Undang Nomor 1 Tahun 2004 tentang Perbendaharaan Negara.

Pemerintah Republik Indonesia. 2010. Undangundang Nomor 71 Tahun 2010 Tentang Standar Akuntansi Pemerintahan. 2010. Jakarta.

Simanjuntak, Binsar H. 2010. Penerapan Akuntansi Berbasis Akrual di Sektor Pemerintahan di Indonesia.Jakarta

Sugiyono.2013.Metode Penelitian Pendidikan. Pendekatan Kuantitatif, Kualitatif, 